\title{
Physico-chemical, microbial and phytotoxicity evaluation of composts from sorghum, finger millet and soybean straws
}

\author{
P. S. Jagadabhi ${ }^{1}$ S. P. Wani ${ }^{1}$ - M. Kaushal ${ }^{2} \cdot$ M. Patil $^{1} \cdot$ A. K. Vemula ${ }^{1} \cdot$ A. Rathore ${ }^{1}$
}

Received: 29 May 2018 / Accepted: 18 December 2018 / Published online: 24 December 2018

(c) The Author(s) 2018

\begin{abstract}
Purpose Composting is an environmentally sustainable alternative for bioconversion of agricultural residues into a nutrientrich product that can enhance soil fertility/microbial diversity and thereby improve agricultural productivity. The goal of the current study was to evaluate the decomposition pattern of the agro-residues and assess the maturity and phytotoxicity of the composts obtained using physico-chemical, microbial and statistical analyses. The study also attempted to determine a threshold germination index (GI) to serve as a maturity index for the composts by conducting seed germination assays with tomato, chickpea and soybean seeds.

Methods Three agricultural residues/straws of Eleusine coracana (finger millet), Sorghum bicolor (sorghum) and Glycine $\max$ (soybean) were subjected to aerobic composting for a period of 60 days to study the impact of saw dust on the decomposition pattern and the ultimate compost quality/characteristics.

Results The results showed efficient decomposition pattern of the agricultural residues characterized by high temperature profiles (up to $70{ }^{\circ} \mathrm{C}$ ), high microbial activity, a sharp decrease in $\mathrm{C} / \mathrm{N}$ ratio of the composting materials, i.e., from an initial $41-61$ to final $10-17$.

Conclusions Statistical evaluation of seed germination assays showed that only the compost obtained from sorghum straw + saw dust was mature and free from any phytotoxicity as all the tested seeds showed higher and statistically significant GIs. It was difficult to attribute a single threshold GI value to indicate maturity of compost and could not further be applied to different types of composts as different seeds responded differently to the same compost.
\end{abstract}

Keywords Straw $\cdot$ Compost $\cdot$ Phytotoxicity $\cdot$ Maturity $\cdot$ Germination index (GI) $\cdot$ Seed germination

\section{Introduction}

India has about 500 million metric tons of biomass availability per year and according to Ministry of new and renewable energy, 200 million tons of agro processing and domestic wastes are generated annually (Kumar et al. 2015). It is further estimated that about 686 metric tons (MT) of gross agro biomass residues are generated annually from 26 different crops of which 234 MT (34\%) are surplus agro residues. Cereals group contribute the highest amount of surplus residue (89 MT) followed by sugarcane (56 MT), horticultural

P. S. Jagadabhi

j.shanthi@cgiar.org; shanthijpr@gmail.com

1 International Crops Research Institute for the Semi-Arid Tropics (ICRISAT), Hyderabad, Telangana 502324, India

2 Present Address: International Institute of Tropical Agriculture (IITA), Hyderabad, Telangana, Tanzania
(23 MT), oilseeds (14 MT), pulses (5 MT) and others (47 MT) (Hiloidhari and Baruah 2014). Such large volume of agricultural biomass residues represents an abundant source of carbon that can be utilized for enrichment of soil organic carbon through composting technology. To control the excessive application of chemical fertilizers that majorly contribute to soil health deterioration and greenhouse gas emissions (GHGs), compost production and application have been receiving greater attention in India as it is an excellent source of humus and nutrients for improving the quality of the soil health (Gabhane et al. 2012).

Composting is a biological decomposition process during which the degradation of solid organic substances takes place under aerobic conditions through the action of various microbial consortia, resulting in a stable, mineral-rich product with humic substances that can be safely applied to the soil (Lashermes et al. 2012). When applied to soil, humic substances in the compost play a significant role in global 
carbon cycling for regulating the degradation and mobility of environmental contaminants and, thus, create favorable conditions for plant growth (Christl et al. 2005; Harrison 2008).

The composting process essentially occurs in three phases; a mesophilic phase during which microbial consortia multiply exponentially in the biomass to initiate the decomposition process, a thermophilic phase during which high rate decomposition occurs due to the increased growth of thermophilic microorganisms and the last phase during which compost undergoes cooling, stabilization and maturation (Ryckeboer et al. 2003). The duration of the composting process largely depends upon the structural composition of biomass (i.e., cellulose, hemicellulose and lignin contents) subjected to composting and the environmental and operating conditions of the composting location/reactor and, thus, can vary from about 45 days to a few months (Diaz et al. 2002). The stability and maturity of the compost are crucial factors to determine whether or not it could be safely applied to soil for nutritional amendments. Because immature and unstable composts can be phytotoxic and may have a negative impact on plant growth, also they can lead to imbalance in mineral contents of the soil due to the presence of high amounts of organic acids and salts characterized by low $(<6)$ or high $\mathrm{pH}(<8)$ and high $\mathrm{EC}(>1)$. Therefore, quality assessment of the composts in terms of maturity and stability is essential for their safe application.

The aim of the current study was to subject different agricultural residues such as finger millet straw (FMS), soy bean straw (SB), sorghum straw (SS) to composting and (1) evaluate their microbial decomposition pattern by monitoring physical, chemical and microbiological parameters (2) to assess the effects of co-composting with saw dust (SD) on process parameters, microbial composition, degradation process/rate and the resulting compost characteristics (3) to assess the maturity of the four different composts obtained by conducting germination assays using three different bioassay plant seeds (tomato, chickpea and soybean) and (4) to understand the responses of different seeds to the same compost while attempting to determine a threshold GI value as a maturity index for the four different composts studied. When a consistent and a threshold GI value for a compost is obtained for the tested seeds, then it can easily be used as a maturity index to determine the quality of the composts obtained from different organic wastes.

In general, composts of high quality should be mature as well as stable. The terms maturity and stability are distinct and have been well discussed in the literature (Iannotti et al. 1993; Epstein 1997; Wu et al. 2000). Maturity is related to the effect of composts on crops and indicates the presence or absence of phytotoxins or inhibitory substances for plant growth. On the other hand, compost stability is a stage in the decomposition of the organic matter (Epstein 1997) and is, therefore, a term related to the microbial abundance/decomposition or microbial respiration activity of the composted matter.

In addition to physico-chemical analyses, maturity can also be measured in terms of germination index (GI) which is based on relatively simple phytotoxicity tests. Phytotoxicity tests are actually germination bioassays that quantify seed growth after the application of compost liquid extracts to the seeds; GI is calculated by the root length and the percentage of germination of selected test plant seeds compared to a control (control is commonly tested using deionized water). The GI of any compost aids in determining the level of toxicity, i.e., low levels of toxicity mainly affects root growth, while high levels of toxicity, affect seed germination. Therefore, GIs lower than $100 \%$ indicate potential phytotoxicity, while values greater than $100 \%$ indicate a positive effect on seed growth, and thus signify a mature compost. A phytotoxicity test does not reveal the underlying reasons for the compost's toxicity but serves only as an indirect measure for quantification of the toxicity for seed growth. Phytotoxicity in the compost extract can be typically due to the presence of partially degraded organic acids, fermentation intermediates, ammonia, salts and heavy metals.

The results of this study are envisioned to help in promoting the composting practices while offering insightful information on the microbial abundance, activity, decomposition pattern, and duration required for composting straw residues and how the quality of composts applied affect seed germination; and such information would be highly valuable for evaluation of composts prepared from different organic agricultural residues for promoting sustainable organic farming by application of environmentally safe composts and lead us to a path of sustainable farming.

\section{Materials and methods}

\section{Raw materials and compost reactors}

The agricultural organic residues viz., Eleusine coracana (finger millet straw), Sorghum bicolor (sorghum straw), Glycine max (soybean straw) were obtained from ICRISAT fields, Patancheru, Telangana, India. All the three straw residues were dried and chopped to $2-4 \mathrm{~cm}$ lengths before subjecting to composting process. Saw dust was obtained from ICRISAT's in-house carpentry workshop. To carry out the composting trials of these residues, four perforated 5001 PVC reactors were used.

\section{Compost preparation}

On day 1 of the experiment, each of the PVC reactors (C1-C3) were filled with $25 \mathrm{~kg}$ straw residues such as finger 
millet straw (C1), sorghum straw (C2) and soybean straw (C3), while the fourth container (C4) was filled with $20 \mathrm{~kg}$ sorghum straw and $5 \mathrm{~kg}$ of saw-dust $(\mathrm{SS}+\mathrm{SD})$. In all the reactors (C1-C4), the straw biomass was filled in 3 layers alternating with cow dung $(5 \mathrm{~kg})$. Rock phosphate was added @ $4 \mathrm{~kg} / 100 \mathrm{~kg}$ of biomass to provide an additional (insoluble) phosphorus source for the decomposition process, while urea was added as an additional nitrogen source @ $0.5 \mathrm{~kg} / 100 \mathrm{~kg}$ of biomass. The initial $\mathrm{C} / \mathrm{N}$ ratio of the composting materials in the reactors was ranging between 41 and 61. To provide aerobic conditions, the mixture was turned once a week throughout the study period (60 days) and water was added frequently (depending on weather conditions) to maintain $60 \%$ of moisture level in all the reactors. Sample collection was done every ten days. Grab sampling was done at four random points in the reactors and were mixed to obtain one representative sample for laboratory analyses.

\section{Microbial activator cultures}

A proprietary microbial activator culture from EXCEL CROP CARE Ltd (Madhyam culture) was used as seed culture in all the compost reactors. The microbial activator culture was applied @ $1 \mathrm{~kg} / \mathrm{ton}$ of biomass as per the instructions given by the supplier.

\section{Seed germination assays}

To confirm the maturity of the composts and to test their phytotoxicity, seed germination assays were conducted under laboratory conditions. Three different types of seeds viz, soybean, tomato and chickpea were used. Composts of finger millet straw (FMS), sorghum straw (SS), soybean straw $(\mathrm{SB})$ and sorghum straw $(\mathrm{SS})+\mathrm{SD}(\mathrm{SS}+\mathrm{SD})$ were tested at three different dilutions/compositions $(25 \%, 50 \%$ and $100 \%$ extracts) for their phytotoxicity as shown in Fig. 1.
The aqueous compost extracts were obtained by weighing $100 \mathrm{~g}$ of each type of compost which was mixed with 11 deionized water (@ 10:1 water volume-in ml and dry weight—in g) in 11 Tarsons' plastic bottles. Bottles were then kept on a shaker to allow mixing for $4 \mathrm{~h}$ at room temperature. The slurry obtained was then vacuum filtered using a $0.45 \mu \mathrm{m}$ filter. The filtered slurries were then used for the germination bioassays. The germination bioassays were conducted in $110 \mathrm{~mm}$ petri plates. In each of the petri plates, a UV-sterilized filter paper (Whatman no. 1) was placed and a liquid volume of $5 \mathrm{ml}$ was maintained. While control assays were filled with $5 \mathrm{ml}$ of deionized water, treatment assays were filled with different dilutions of compost slurries + deionized water. For example, if the compost extract application is $25 \%$, then $1.75 \mathrm{ml}$ of compost slurry $+3.25 \mathrm{ml}$ of deionized water were used. After adding compost slurry and deionized water five seeds were placed in each of the petri plates. Both for control and treatment assays five replicates were maintained. The petriplates were incubated at $25{ }^{\circ} \mathrm{C}$ in the dark for 5 days (adapted from Zucconi et al. $1981 \mathrm{a}, \mathrm{b})$.

\section{Analyses and calculations}

The temperature in the compost reactors $(\mathrm{C} 1-\mathrm{C} 4)$ was recorded every half-an-hour using a data-logger during the experimental period (60 days). Samples were taken at different stages of the composting process $(0,1,10,20,30,40$, 50 and 60 days) to investigate the decomposition process/ rates in detail. The total solids (TS) and volatile solids (VS) content of all the straw residues were measured according to standard methods (APHA 1998). The parameters $\mathrm{pH}$ and EC were measured using Eutech waterproof portable meter, Cyberscan series 600. The dried samples were ground and used to analyze the elements, N, P, K, Zn, B, Fe, Cu, Mn, Ca, $\mathrm{Mg}, \mathrm{B}$ and S. Macro- and micro-elements were analyzed by inductively coupled plasma optical emission spectrometry
Fig. 1 Experimental design for the seed germination assays of tomato, soybean and chickpea

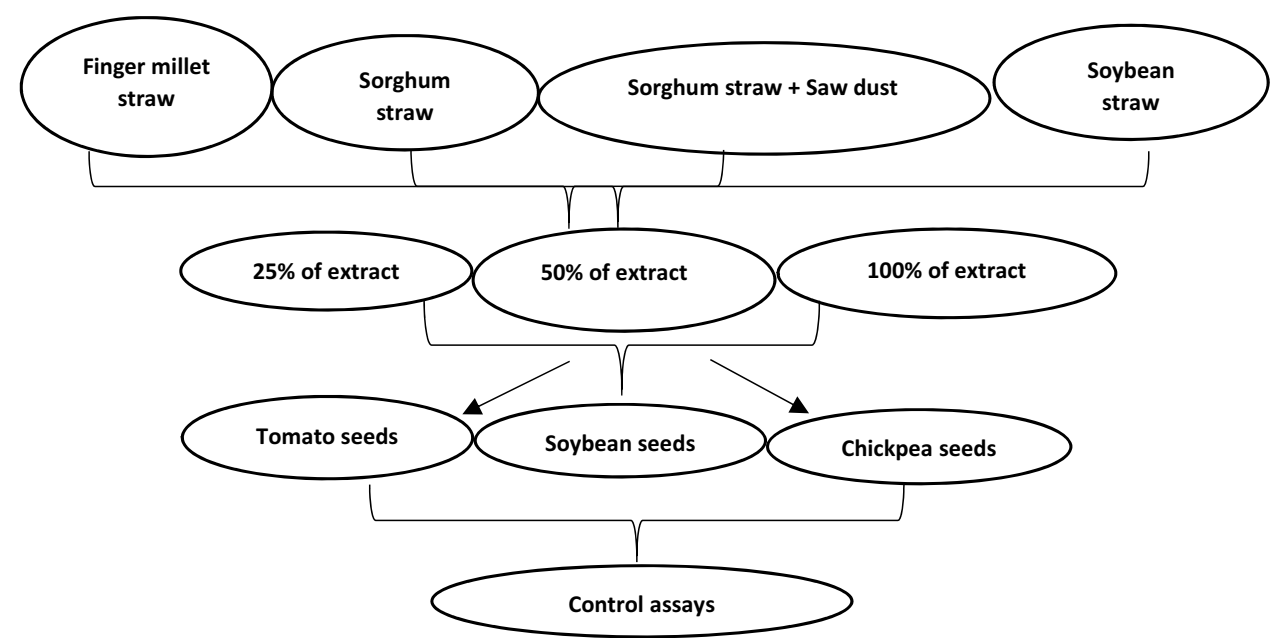


(ICPOES) following $\mathrm{H}_{2} \mathrm{O}_{2}$ digestion for $\mathrm{Fe}$, $\mathrm{Zn}$, etc. (Matthew et al. 2011) and sulfuric acid-selenium digestion method for N, P, etc. (Sahrawat et al. 2002).

The extraction and fractionation of humic substances were carried out according to method proposed by California Department of Food and Agriculture (CDFA) 1999. The germination index was analyzed by the method of Tiquia et al. (1996) using soy bean, tomato and chickpea seeds. The seed germination and the root length were measured after 5 days. The relative seed germination (SG), relative root elongation (RE) and germination index (GI) were calculated as follows:

$\mathrm{SG} \%=\frac{\text { Number of seeds germinated in extract }}{\text { Number of seeds germinated in control }} \times 100$

$\mathrm{RE} \%=\frac{\text { Mean root length in extract }}{\text { Mean root length in control }} \times 100$

$\mathrm{GI} \%=\frac{\mathrm{SG} \% \times \mathrm{RE} \%}{100}$

\section{Statistical analyses}

The experimental trial was laid out in completely randomized design with four levels of composts and three levels of seed types. Germination index (GI) data were analyzed by SAS general linear model (GLM) procedure (SAS Institute Inc. 2015) for all the three tested seeds (i.e., tomato, chickpea and soybean). Considering compost and seed type as fixed, least square means were estimated for main and interaction effects. Least Significant Difference (LSD) was performed for significant factors.

\section{Results and discussion}

\section{Chemical characteristics of the agricultural residues}

The chemical characteristics of the straw residues are presented in Table 1. The straw residues tested in the current study were very dry with low moisture content $(<25 \%)$, high total solid (TS) and volatile solids (VS) contents ranging from 62 to $78 \%$. Low moisture (high TS) and high organic contents (high VS) of the substrates indicate the complexity of the ligno-cellulosic structure of the straw residues and also indicate that a lengthy period of time would be required for composting the straw biomass. Carbon contents ranged from 40 to $44 \%$ in all the three straws while $48 \%$ was recorded in SD (Table 1). High EC of finger millet straw indicates the extent of minerals present in the substrate. The $\mathrm{pH}$ of the straws was also below neutral indicating acidic nature of the substrates.

\section{Temperature profiles}

The most significant indicator of microbiological activity in a composting heap is its temperature profile (Cáceres et al. 2015). The temperature profiles of all the four composting trials are given in Fig. 2. The composting process could be essentially divided into four phases: (1) a mesophilic phase that occurred in the initial days $0-1$; (2) a high temperature, thermophilic phase that took place during days 2-10; (3) a drop in temperature days from day 8 to day 10 and (4) a maturation phase which occurred after days 30-45 depending on the type and complexity of the composting substrate (Villar et al. 2016). In the present composting trials, the temperature peaked up to $70{ }^{\circ} \mathrm{C}$ in the composting reactors of sorghum straw and sorghum straw + saw dust at a depth $75 \mathrm{~cm}$ and remained between 55 and $70{ }^{\circ} \mathrm{C}$ during first 10 days. On the other hand, temperature in composting reactors of finger millet straw and soybean straw at $75 \mathrm{~cm}$ depth was observed to be $42-60{ }^{\circ} \mathrm{C}$ during the first 10 days and then declined to less than $40{ }^{\circ} \mathrm{C}$. However, temperatures were comparatively lower in finger millet straw and soybean straw reactors probably due to the drier or recalcitrant nature of these straws as indicated by their high TS/VS contents which offer greater structural complexity resisting microbial degradation (Mhindu et al. 2013). In all the composting reactors, high temperatures $\left(>50{ }^{\circ} \mathrm{C}\right)$ during the first 10 days

Table 1 Initial chemical characteristics of the straw residues, finger millet straw (FMS), sorghum straw (SS) and soybean (SB) straw and saw dust (SD)

\begin{tabular}{|c|c|c|c|c|c|c|c|c|}
\hline \multirow[t]{2}{*}{ Straw residue } & \multirow[t]{2}{*}{$\mathrm{pH}$} & \multirow[t]{2}{*}{$\mathrm{EC}\left(\mu \mathrm{S} \mathrm{cm}^{-1}\right)$} & \multicolumn{6}{|c|}{ Initial chemical characteristics } \\
\hline & & & TS (\%) & VS ( $\%$ of TS) & $\mathrm{C}(\%)$ & $\mathrm{N}(\%)$ & $\mathrm{P}(\%)$ & $\mathrm{K}(\%)$ \\
\hline Cow dung & 7.4 & NA & $18 \pm 1.2$ & $15.8 \pm 1.2$ & NA & $1.51 \pm 0.1$ & $0.52 \pm 0$ & $1.21 \pm 0$ \\
\hline FMS & 6.8 & 0.78 & $74.5 \pm 0.2$ & $66.8 \pm 0.2$ & $40.45 \pm 0$ & $0.66 \pm 1.1$ & $0.18 \pm 0.1$ & $1.61 \pm 0.1$ \\
\hline SS & 6.5 & 0.21 & $62.2 \pm 0.1$ & $55.8 \pm 0.1$ & $43.06 \pm 0.1$ & $1.04 \pm 0.0$ & $0.13 \pm 0$ & $1.23 \pm 0.1$ \\
\hline SB & 6.8 & 0.30 & $78.6 \pm 1.4$ & $68.2 \pm 1.2$ & $44.57 \pm 1.2$ & $0.79 \pm 0.0$ & $0.15 \pm 0$ & $0.57 \pm 0$ \\
\hline SD & 4.5 & 0.28 & $80.2 \pm 1.2$ & $72.6 \pm 0.1$ & $48.26 \pm 1.1$ & NA & & \\
\hline
\end{tabular}

$N A$ not analyzed 
Fig. 2 Temperature profiles recorded for sorghum straw, finger millet straw, soybean straw and sorghum straw + saw dust during composting process in the PVC reactors
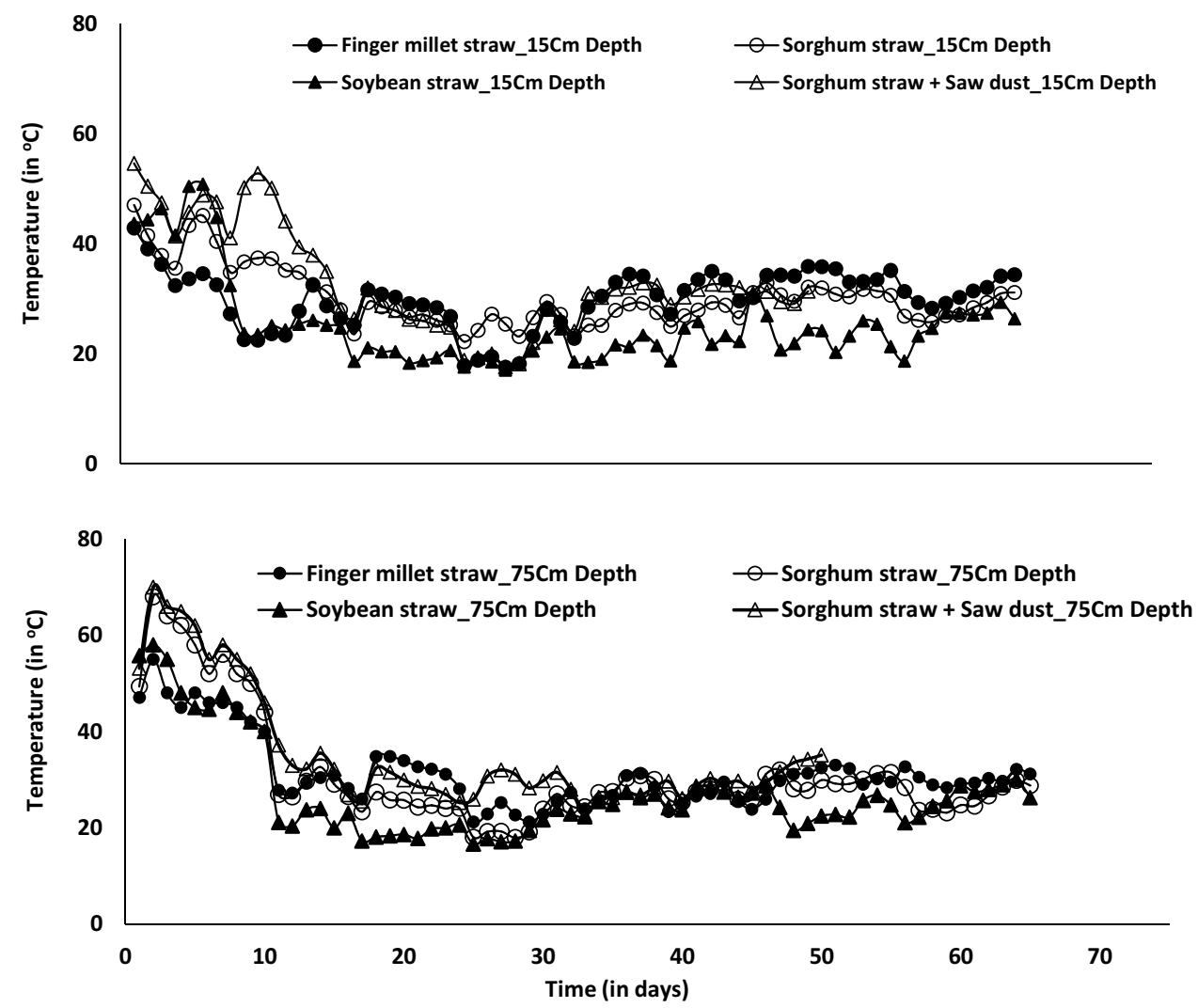

indicate successful initiation of hydrolytic/fermentation phase of the composting process and reflect a very active decomposition process in the reactors. Literature indicates that the optimum temperature range required for efficient decomposition of ligno-cellulosic materials is around 50-60 ${ }^{\circ} \mathrm{C}$ (Wong et al. 2001). Due to the rapid degradation of the readily available soluble organic and nitrogenous compounds, high temperatures are observed and a lot of heat is generated due to the microbial respiration (Bernal et al. 2009). High temperatures $\geq 50{ }^{\circ} \mathrm{C}$ in the composting reactors essentially contribute to disinfection of the composting materials (pathogenic organisms arising from cow dung used in the composting process).

Temperatures dropped in all the reactors soon after the weekly turning (aeration) of the composting materials, as a result of oxygen flow through the compost and removal of heat released due to microbial respiration (Himanen and Hanninen 2011). High temperatures (40-60 ${ }^{\circ} \mathrm{C}$ ) were also observed at the $15 \mathrm{~cm}$ depth in all the composting reactors indicating high microbial activity during the first 10 days. In all the reactors, temperatures reached near ambient conditions 15 days after the composting process initiated indicating the end of thermophilic microbial activity (Nolan et al. 2011). The temperature dynamics were observed to be following a typical composting pattern thus contributing to efficient microbial degradation process (Cáceres et al. 2015; Guo et al. 2012). When temperatures started decreasing to ambient conditions, the degradation process slowed down which was also indicated by decreased microbial activity.

\section{pH and EC}

The initial $\mathrm{pH}$ of all the straws and saw dust was low ranging from 6 to 7 and this $\mathrm{pH}$ further dropped between days 1-10 of the composting process, i.e., when the temperatures in all the composting reactors were high because of increased microbial fermentation activity (Fig. 2). During the fermentation process, degradation of readily available/ soluble organic substances takes place and as a result $\mathrm{pH}$ decreases, due to the release of organic acids. The $\mathrm{pH}$ slowly rose to 8 and above after 10 days when temperature as well as thermophilic microbial activity started to decrease. By the end of the first month, $\mathrm{pH}$ ranged 7.5-8 indicating the completion of the decomposition process of readily degradable compounds and indicating the progress of maturity of the composted materials. The increased $\mathrm{pH}$ also indicates the increased ammonium contents in the composted materials. Turning or aeration of the composting materials in the reactors during the first 10 days did not increase the $\mathrm{pH}$ significantly probably, due to the on-going thermophilic fermentation activity.

In the current composting trials, it was observed that, as the composting time proceeded, electrical conductivity (EC) gradually increased with time in all the composting reactors 
(Mupondi et al. 2006; Manios 2004). This is due to the fact that as composting progresses, organic substances undergo loss of weight due to mineralization into soluble forms and subsequently become concentrated due to drying. The drying process enables accumulation of mineral salts such as phosphate and ammonium ions contributing to higher EC (Mhindu et al. 2013). In the present study, EC of all the compost materials increased from the initial $0.2-0.7$ to final $0.8-1.2 \mathrm{mS} \mathrm{cm}^{-1}$ which is still within the limits of favorable $\mathrm{EC}$ for enabling seed germination. The EC of composts from sorghum straw and sorghum straw + saw dust showed $<1$ $\mathrm{mS} \mathrm{cm}{ }^{-1}$ indicating that they will not cause any phytotoxicity to the plants due to the lower content of accumulated salts, than the composts obtained from finger millet straw and soybean straw which showed higher EC (Fig. 3). Usually, high EC of composts $\left(>4 \mathrm{dS} \mathrm{m}^{-1}\right.$ ) was reported to inhibit seed germination and thus, seed germination assays are used as a means to test the maturity and phytotoxicity of the composts (Nakasaki and Marui 2011; Singh and Nain 2014).

\section{Changes in $\mathrm{C} / \mathrm{N}$ ratio}

The $\mathrm{C} / \mathrm{N}$ ratio of the composting substrates is an excellent indicator of maturity as it significantly influences the microbiological growth and thus the rates of decomposition (Chauhan and Singh 2013). High C/N ratio indicates the presence of unutilized complex carbon content, while a decrease in $\mathrm{C} / \mathrm{N}$ ratio $(<25: 1)$ indicates efficient decomposition process (Pan et al. 2012). Substrates having higher carbon and nitrogen contents generally require more time for completion of the maturation phase. In the present study, the initial $\mathrm{C} / \mathrm{N}$ ratios of the composting materials ranged from 41 to 61 (Fig. 3), which decreased substantially by day 60 to $10-17$ and became stable later on (Fig. 3). The results revealed that irrespective of type of crop residues, the $\mathrm{C} / \mathrm{N}$ ratio decreased significantly and progressively during the composting process. The decrease in $\mathrm{C} / \mathrm{N}$ ratio is a result of decomposition or breakdown of the compostable mixtures against time to $\mathrm{CO}_{2}$, while the $\mathrm{N}$ content per unit material increased, which contributed to the decrease in $\mathrm{C} / \mathrm{N}$ ratio. At the final stage of composting, the highest $\mathrm{C} / \mathrm{N}$ ratio (17.3) was recorded in finger millet straw substrate followed by soybean straw (12), sorghum straw + saw dust (11.3), and sorghum straw (10.5). The maturity of the compost also depends upon the chemical nature (cellulose, hemicellulose and lignin contents) of the substrates with varying $\mathrm{C} / \mathrm{N}$ ratios. Lignin contents of the straws used in the current study were reported to be in the order of soybean straw $>$ finger millet straw and $>$ sorghum straw $(17.6 \%, 15-16 \%$ and $7 \%$, respectively) (Badu et al. 2011; McIntosh 2010). Clearly, the $\mathrm{C} / \mathrm{N}$ ratios of these straws also decreased in the same pattern, i.e., lower lignin content in the substrate resulted in lower
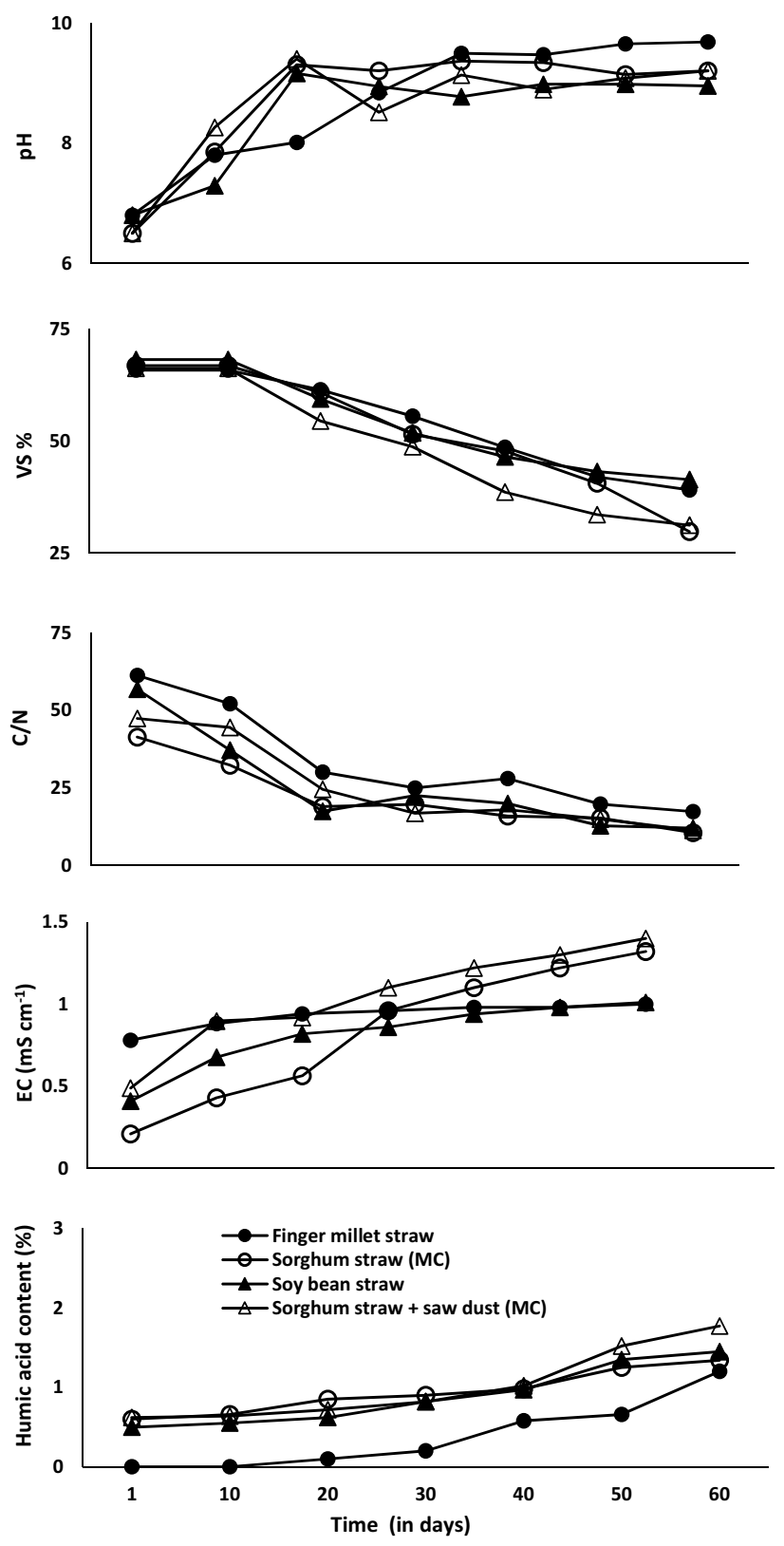

Fig. 3 Decomposition pattern of the straws measured in terms of $\mathrm{pH}$, $\mathrm{C} / \mathrm{N}$ ratio, volatile solids (VS\%), electrical conductivity (EC) and humic acid content (\%) in the composting reactor

$\mathrm{C} / \mathrm{N}$ ratio by the end of composting period such as sorghum straw $<$ soybean straw $<$ finger millet straw.

The $\mathrm{C} / \mathrm{N}$ ratio below 20 was reported to be a good indicator of compost maturity, with a ratio of 15 or less being ideal (Goyal et al. 2005). It was also reported that ideally, the $\mathrm{C} / \mathrm{N}$ ratio of mature compost should be about 10 , which, however, is very difficult to achieve, due to the presence of complex and recalcitrant organic compounds that resist decomposition due to their physical or chemical properties (Goyal et al. 2005). Some studies reported that a $\mathrm{C} / \mathrm{N}$ ratio 
below 20 is indicative of an acceptable maturity, with a ratio of 15 or even less being preferable (Rashad et al. 2010). The composting of materials with low $\mathrm{C} / \mathrm{N}$ ratio results in more $\mathrm{N}$ losses than in high $\mathrm{C} / \mathrm{N}$ ratio wastes (Sánchez-Monedero et al. 2001; Wei et al. 2015). Therefore, in the present study, all the straws except finger millet underwent efficient composting process as indicated by their lower final $\mathrm{C} / \mathrm{N}$ ratios.

\section{Changes in volatile solids (VS) removal}

The VS content (organic content) of the composting materials in all the reactors decreased with time (Fig. 3) due to microbial decomposition of organic matter. The overall VS destruction (over a period of 60 days) in composting reactors of sorghum straw and sorghum straw + saw dust was observed to be higher (56\% and 58\%, respectively) than in finger millet straw (40\%) and in soybean straw (39\%). This result is clearly due to higher moisture and lower TS and VS contents observed in sorghum straw than in the remaining straws/saw dust (Table 1). Lower VS (higher moisture) content in sorghum straw reduced the carbon load in the reactor (better $\mathrm{C} / \mathrm{N}$ ratio) and enabled better microbial activity as well as decomposition. In the composting reactors of finger millet straw and soybean straw, higher VS load would have created imbalance in $\mathrm{C} / \mathrm{N}$ ratio resulting in reduced microbial activity/decomposition. Also, finger millet straw and soybean straw indicate higher structural recalcitrance to microbial destruction due to their higher VS contents and thus lower VS destruction was observed.

\section{Elemental and NPK dynamics}

The nutrient value of the compost is dependent upon its macronutrients composition. The total $\mathrm{N}, \mathrm{P}$, and $\mathrm{K}$ contents increased with composting time. The total $\mathrm{N}$ content obtained in the present study for all the composts by day 60 was in the range from 2.03 to $2.65 \%$ (Fig. 4) while P contents were in the range of $0.79-1.85 \%$ and $\mathrm{K}$ was found to be in the range of $1.52-2.42 \%$. Nitrogen content was highest in soybean compost, whereas $\mathrm{P}$ and $\mathrm{K}$ contents were found to be highest in sorghum straw compost $(1.85 \%$ and $2.42 \%$, respectively). The NPK contents observed in the present study were found to be in agreement with the proposed elemental standards for composts by the Indian fertilizer control order, 1985 (Singh and Nain 2014). The $\mathrm{N}$ contents of different straw composts were higher than those reported by Moharana and Biswas (2016) for chickpea stover $(1.63 \%)>$ rice straw $(1.51 \%)>$ mustard stover $(1.50 \%)>$ wheat straw $(1.32 \%)>$ tree leaves $(1.21 \%)$ composts after 120 days of composting period. The increase in $\mathrm{N}$ content in the compost materials is due to the loss of dry matter content (as total $\mathrm{C}$ ) in the form of $\mathrm{CO}_{2}$ and water vapour loss during natural evaporation and microbial

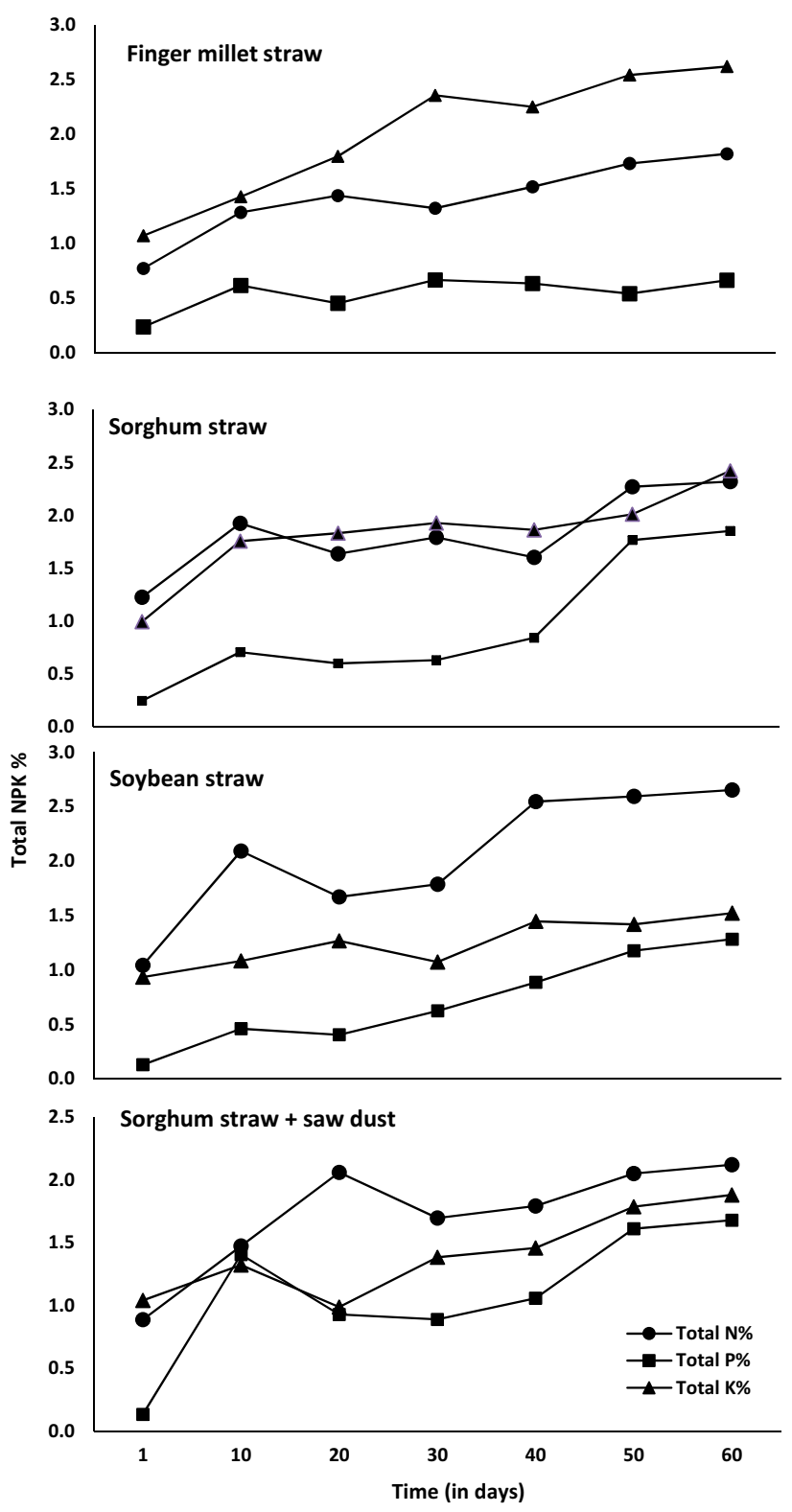

Fig. 4 NPK dynamics of the finger millet straw, sorghum straw, soybean straw and sorghum straw + saw dust during the composting process

decomposition processes. Several other studies also reported similar results for NPK contents (Pan et al. 2012; Wei et al. 2015; Mhindu et al. 2013).

Other elements such as $\mathrm{Ca}, \mathrm{Mg}, \mathrm{B}$ and $\mathrm{S}$ and trace elements $\mathrm{Fe}, \mathrm{Mn}, \mathrm{Cu}$ and $\mathrm{Zn}$ in all the composts were found to be increasing in concentration with time indicating active decomposition pattern of the organic material in straws (Table 2). However, Calcium (Ca) is found to be particularly high in all composting materials and this could be due to the addition of calcium amended rock phosphate at the beginning of the experimental period. The remaining elemental contents (except $\mathrm{Ca}$ ) were found to be within the 
Table 2 Elemental dynamics (in $\mathrm{g}^{-1}$ ) in finger millet straw (FMS), sorghum straw (SS), soybean straw (SB) and sorghum straw (SS) + saw dust compost pits $(\mathrm{SS}+\mathrm{SD})$

\begin{tabular}{|c|c|c|c|c|c|c|c|c|}
\hline \multirow{2}{*}{$\begin{array}{l}\text { Time in days } \\
\text { FMS }\end{array}$} & \multicolumn{8}{|c|}{$\left(\right.$ Concentration in $\mathrm{g}^{-1}$ ) } \\
\hline & $\mathrm{Fe}$ & $\mathrm{Cu}$ & $\mathrm{Mn}$ & $\mathrm{Zn}$ & $\mathrm{Ca}$ & $\mathrm{Mg}$ & B & $\mathrm{S}$ \\
\hline 0 & $0.11 \pm 0.2$ & $0.00 \pm 0$ & $0.07 \pm 0.3$ & $0.02 \pm 0.1$ & $10.63 \pm 0.2$ & $3.96 \pm 1.1$ & $0.01 \pm 0$ & $3.1 \pm 0.2$ \\
\hline 1 & $0.54 \pm 0.1$ & $0.00 \pm 0$ & $0.1 \pm 0.3$ & $0.04 \pm 0.1$ & $11.97 \pm 0.4$ & $4.2 \pm 1.4$ & $0.01 \pm 0.1$ & $2.8 \pm 0.2$ \\
\hline 10 & $1.3 \pm 0.3$ & $0.01 \pm 0$ & $0.25 \pm 0.1$ & $0.06 \pm 0.1$ & $17.57 \pm 0.4$ & $4.83 \pm 1.2$ & $0.02 \pm 0.2$ & $3.4 \pm 0.8$ \\
\hline 20 & $1.8 \pm 0.2$ & $0.01 \pm 0$ & $0.19 \pm 0.2$ & $0.06 \pm 0.1$ & $15.45 \pm 0.3$ & $6.3 \pm 1.8$ & $0.02 \pm 0.2$ & $4.1 \pm 0.6$ \\
\hline 30 & $0.97 \pm 0.3$ & $0.0 \pm 0$ & $0.31 \pm 0.3$ & $0.05 \pm 0$ & $25.47 \pm 1.2$ & $6.3 \pm 0.8$ & $0.02 \pm 0.1$ & $4.4 \pm 1.1$ \\
\hline 40 & $1.26 \pm 0.3$ & $0.01 \pm 0$ & $0.31 \pm 0.3$ & $0.08 \pm 0$ & $40.85 \pm 0.1$ & $6.6 \pm 0.3$ & $0.02 \pm 0$ & $4.2 \pm 1.4$ \\
\hline 50 & $1.85 \pm 0.1$ & $0.0 \pm 0.2$ & $0.24 \pm 0.3$ & $0.07 \pm 0$ & $44.17 \pm 1.4$ & $8.4 \pm 0.3$ & $0.02 \pm 0$ & $4.5 \pm 1.8$ \\
\hline 60 & $2.4 \pm 0.2$ & $0.09 \pm 0.2$ & $0.01 \pm 0.2$ & $0.79 \pm 0$ & $60.88 \pm 2.1$ & $11.44 \pm 1.6$ & $0.01 \pm 0$ & $4.2 \pm 2.2$ \\
\hline SS & $\mathrm{Fe}$ & $\mathrm{Cu}$ & $\mathrm{Mn}$ & $\mathrm{Zn}$ & $\mathrm{Ca}$ & $\mathrm{Mg}$ & B & $\mathrm{S}$ \\
\hline 0 & $0.11 \pm 0$ & $0.00 \pm 0$ & $0.03 \pm 0$ & $0.02 \pm 0$ & $3.73 \pm 0.4$ & $1.67 \pm 0.8$ & $0.00 \pm 0$ & $0.90 \pm 0$ \\
\hline 1 & $2.83 \pm 1.1$ & $0.01 \pm 0$ & $0.12 \pm 0.1$ & $0.03 \pm 0$ & $5.88 \pm 0.5$ & $2.73 \pm 0.2$ & $0.02 \pm 0$ & $1.34 \pm 0.1$ \\
\hline 10 & $1.27 \pm 0.3$ & $0.01 \pm 0$ & $0.25 \pm 0.1$ & $0.04 \pm 0$ & $13.84 \pm 1.6$ & $3.51 \pm 0.3$ & $0.01 \pm 0$ & $1.85 \pm 0.3$ \\
\hline 20 & $1.36 \pm 0.2$ & $0.01 \pm 0$ & $0.31 \pm 0.2$ & $0.04 \pm 0$ & $15.56 \pm 1.2$ & $3.40 \pm 0.2$ & $0.01 \pm 0$ & $1.84 \pm 0.3$ \\
\hline 30 & $1.05 \pm 0.2$ & $0.01 \pm 0.1$ & $0.21 \pm 0.1$ & $0.04 \pm 0$ & $13.47 \pm 1.2$ & $3.08 \pm 0.5$ & $0.01 \pm 0.1$ & $1.66 \pm 0.2$ \\
\hline 40 & $4.56 \pm 0.3$ & $0.01 \pm 0.1$ & $1.58 \pm 0.4$ & $0.05 \pm 0$ & $93.84 \pm 1.6$ & $3.64 \pm 0.2$ & $0.03 \pm 0.1$ & $1.76 \pm 0.3$ \\
\hline 50 & $4.14 \pm 1.2$ & $0.02 \pm 0$ & $1.13 \pm 0.3$ & $0.06 \pm 0$ & $65.85 \pm 1.2$ & $4.96 \pm 0.3$ & $0.03 \pm 0.1$ & $2.26 \pm 0.4$ \\
\hline 60 & $7.17 \pm 1.6$ & $0.07 \pm 0$ & $1.1 \pm 0.20$ & $2.68 \pm 0.6$ & $126.28 \pm 1.4$ & $5.49 \pm 0.4$ & $0.03 \pm 0.1$ & $2.28 \pm 1.2$ \\
\hline Time in days & \multicolumn{8}{|c|}{ (Concentration in $\mathrm{g}^{-1}$ ) } \\
\hline SB & $\mathrm{Fe}$ & $\mathrm{Cu}$ & $\mathrm{Mn}$ & $\mathrm{Zn}$ & $\mathrm{Ca}$ & $\mathrm{Mg}$ & B & $\mathrm{S}$ \\
\hline 0 & $9.76 \pm 1.1$ & $0.02 \pm 0$ & $0.43 \pm 0$ & $0.03 \pm 0$ & $8.6 \pm 0.1$ & $5.0 \pm 0.25$ & $0.06 \pm 0.2$ & $0.80 \pm 0.1$ \\
\hline 1 & $9.13 \pm 1.2$ & $0.00 \pm 0$ & $0.03 \pm 0$ & $0.01 \pm 0$ & $6.6 \pm 1.2$ & $2.8 \pm 0.2$ & $0.02 \pm 0.2$ & $0.71 \pm 0.1$ \\
\hline 10 & $9.03 \pm 0.8$ & $0.01 \pm 0.1$ & $0.22 \pm 0.1$ & $0.03 \pm 0$ & $14.2 \pm 1.1$ & $4.9 \pm 0.36$ & $0.04 \pm 0$ & $1.67 \pm 0.2$ \\
\hline 20 & $9.85 \pm 0.6$ & $0.02 \pm 0.1$ & $0.34 \pm 0.1$ & $0.04 \pm 0$ & $17.1 \pm 0.6$ & $3.4 \pm 0.32$ & $0.02 \pm 0$ & $1.64 \pm 0.2$ \\
\hline 30 & $9.89 \pm 0.8$ & $0.01 \pm 0$ & $0.36 \pm 0.1$ & $0.02 \pm 0$ & $31.9 \pm 0.8$ & $5.6 \pm 0.2$ & $0.05 \pm 0$ & $1.49 \pm 0.2$ \\
\hline 40 & $9.92 \pm 0.7$ & $0.01 \pm 0$ & $0.40 \pm 0.1$ & $0.04 \pm 0$ & $40.4 \pm 0.3$ & $6.7 \pm 0.2$ & $0.05 \pm 0$ & $2.52 \pm 0.3$ \\
\hline 50 & $9.90 \pm 0.8$ & $0.02 \pm 0$ & $0.95 \pm 0.1$ & $0.05 \pm 0$ & $54.2 \pm 0.3$ & $8.3 \pm 0.31$ & $0.06 \pm 0$ & $2.58 \pm 0.3$ \\
\hline 60 & $9.90 \pm 1.2$ & $0.09 \pm 0.1$ & $0.02 \pm 0$ & $1.86 \pm 0.2$ & $92.3 \pm 0.2$ & $8.1 \pm 0.27$ & $0.03 \pm 0$ & $2.58 \pm 03$ \\
\hline $\mathrm{SS}+\mathrm{SD}$ & $\mathrm{Fe}$ & $\mathrm{Cu}$ & $\mathrm{Mn}$ & $\mathrm{Zn}$ & $\mathrm{Ca}$ & $\mathrm{Mg}$ & B & $\mathrm{S}$ \\
\hline 0 & $0.11 \pm 0.1$ & $0.00 \pm 0.1$ & $0.03 \pm 0$ & $0.02 \pm 0$ & $3.7 \pm 0$ & $1.67 \pm 0$ & $0.00 \pm 0$ & $0.90 \pm 0$ \\
\hline 1 & $4.20 \pm 0.3$ & $0.01 \pm 0.1$ & $0.14 \pm 0.1$ & $0.02 \pm 0$ & $4.8 \pm 0.4$ & $2.47 \pm 1.2$ & $0.02 \pm 0$ & $0.85 \pm 0$ \\
\hline 10 & $2.06 \pm 0.3$ & $0.01 \pm 0.2$ & $0.58 \pm 0.2$ & $0.04 \pm 0$ & $26.3 \pm 0.6$ & $2.85 \pm 1.1$ & $0.02 \pm 0$ & $1.65 \pm 0.6$ \\
\hline 20 & $4.98 \pm 0.2$ & $0.01 \pm 0.2$ & $1.90 \pm 0.2$ & $0.07 \pm 0$ & $75.2 \pm 0.2$ & $4.71 \pm 0.9$ & $0.05 \pm 0.1$ & $1.69 \pm 0.5$ \\
\hline 30 & $2.29 \pm 0.2$ & $0.02 \pm 0.4$ & $0.31 \pm 0.1$ & $0.04 \pm 0.2$ & $23.1 \pm 0.3$ & $3.30 \pm 0.2$ & $0.02 \pm 0$ & $1.64 \pm 0.3$ \\
\hline 40 & $4.06 \pm 0.2$ & $0.02 \pm 0.3$ & $0.53 \pm 0.1$ & $0.04 \pm 0.1$ & $35.9 \pm 0.3$ & $3.62 \pm 0.5$ & $0.03 \pm 0$ & $1.80 \pm 0.3$ \\
\hline 50 & $4.52 \pm 0.3$ & $0.02 \pm 0.1$ & $0.80 \pm 0.1$ & $0.05 \pm 0.1$ & $48.3 \pm 0.3$ & $4.88 \pm 1.2$ & $0.03 \pm 0.1$ & $2.00 \pm 0.3$ \\
\hline 60 & $7.03 \pm 0.8$ & $0.07 \pm 0.1$ & $0.77 \pm 0.2$ & $1.10 \pm 0.1$ & $50.5 \pm 0.4$ & $5.97 \pm 1.1$ & $0.01 \pm 0$ & $0.10 \pm 0.2$ \\
\hline
\end{tabular}

standard limits for composts according to Indian fertilizer control order (1985) as well as in agreement with several other research efforts using different ligno-cellulosic wastes including food and municipal solid wastes (Hseu 2004; Awasthi et al. 2014; Singh and Nain 2014; Hanc et al. 2014). Metal contents in the composts were found to be within the acceptable limits and are essential for the plant growth and soil fertility management (Yadav and Garg 2011).

\section{Changes in microbial activity}

The prerequisite qualities for a compost to be safely applied to soil are a high degree of stability and maturity, indicated by a stable organic matter content, the absence of phytotoxic compounds and the absence of plant or animal pathogens (Bernal et al. 2009). In the present study, growth trend of bacterial and fungal populations followed a pattern typically 
observed during the composting process, i.e., higher activity until day 30 and a decline thereafter (Fig. 5). On day 1 , the microbial (bacterial and fungal) population in reactors of finger millet straw and sorghum straw was comparatively lower than that observed in reactors of soybean straw and sorghum straw + saw dust and this could be due to slow adaptation of microbial populations in these straws. In the composting reactor of sorghum straw + saw dust, the microbial population was consistently higher than the rest of the straw treatments indicating better decomposition rates as also confirmed by other parameters such as higher VS destruction, higher $\mathrm{EC}$ and $\mathrm{pH}$ conditions (close to neutral) (Fig. 3). Higher microbial activity in sorghum straw + saw dust could be clearly due to the availability of additional porosity (Troy et al. 2012) due to the presence of saw dust. Additional porosity offers additional aeration and thus additional aerobic decomposition. Temperatures gradually decreased to ambient levels after a period of elevation during first ten days and as a result the decomposition process of organic matter stabilized.

The stability and maturity of compost are important factors for compost manufacturers as well as for end users, because unstable and immature composts could contain high microbial activity and intermediate organic compounds (such as organic acids). Immature composts affect the concentration of oxygen in the soil and may immobilize nitrogen present in the soil, thus causing critical N-deficiencies in the crops (Zucconi et al. 1981a, b; Hue and Liu 1995).

The maturity of compost is also related to the presence of humic acids (HA) in the composts. HAs are normally generated towards the last stage of composting (Veeken et al. 2000), which requires several weeks to a few months (Inbar et al. 1990). They are extremely important soil components because they constitute a stable fraction of carbon, thus regulating the carbon cycle and the release of nutrients, including nitrogen, phosphorus and sulfur (Stevenson 1984). In this study, humic acid (HA) content in all the composting reactors increased with time $(0.001 \%$ to $1.85 \%)$ indicating that the microbial decomposition occurred efficiently (Fig. 3). Compost maturity has been reported to be closely related to the presence of humic acids (Tiquia 2005). Because, after composting, humic acid content is significantly increased contributing to the stability of soil organic matter and thus indicating that the compost is mature enough for subsequent land application (Zhou et al. 2014). Humic substances are generated during microbial decomposition/ activity in two ways (Lopez et al. 2002) (1) lignin derivatives are oxidized from side chains of lignin which form the core structure of humic substances, and (2) during the
Fig. 5 Microbial activity profile during the composting of finger millet straw, sorghum straw, soybean straw and sorghum straw + saw dust during the composting process
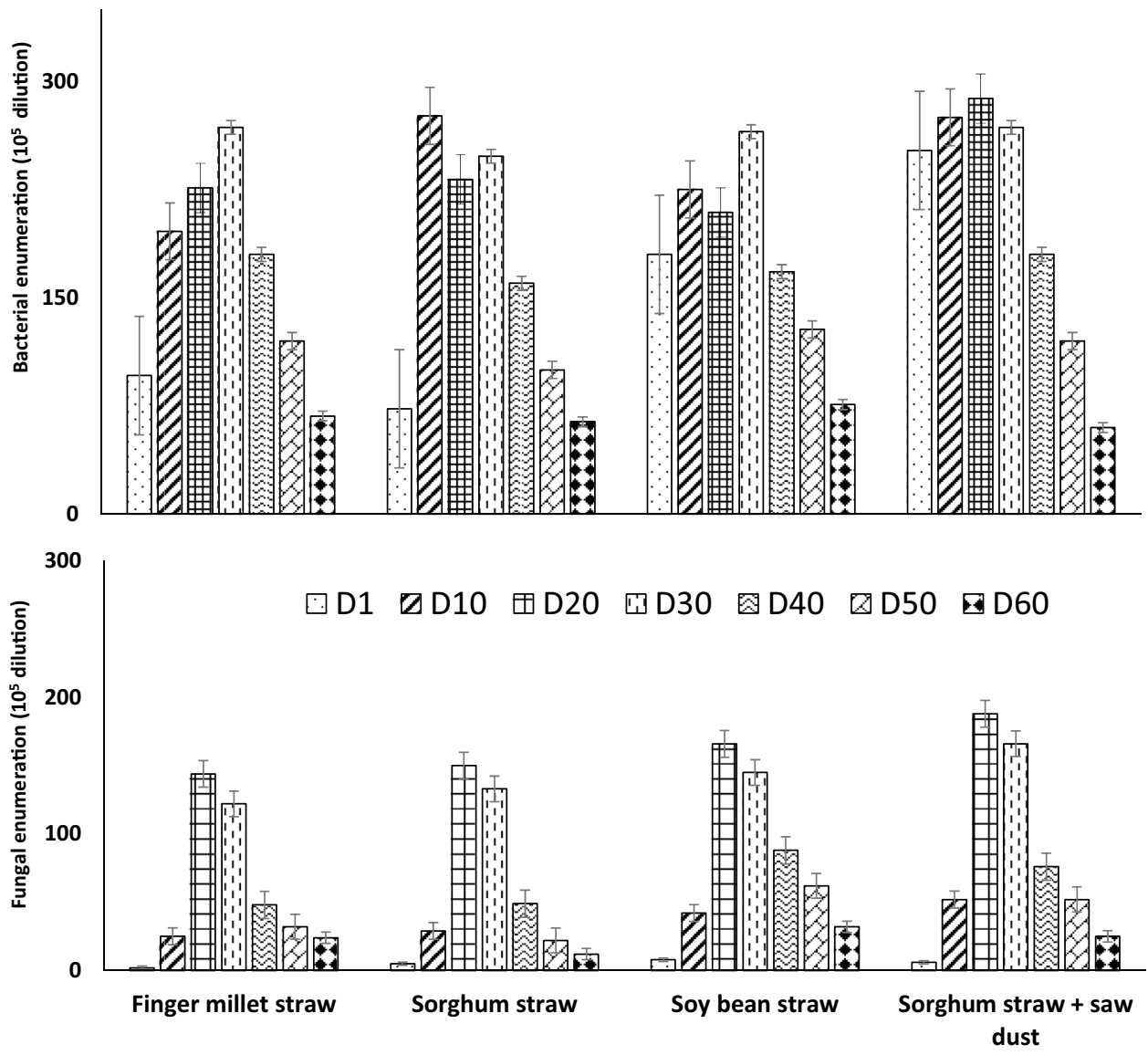
polymerization of monomers. In the present study, humic acid content was observed to be higher in the composting reactor of sorghum straw + saw dust (HA-1.85\%) than in sorghum straw (1.65\%), soybean straw (1.52\%) and in finger millet straw (1.42\%). Therefore, composting materials that contain higher amounts of lignin may contribute to accelerated formation of humic substances (Zhou et al. 2014).

Lignin contents in literature studies were reported to be in the order of saw dust $>$ soybean straw $>$ finger millet straw and $>$ sorghum straw $(27-34 \%, 17.6 \%, 15-16 \%$ and $7 \%$, respectively) (Badu et al. 2011; McIntosh 2010). In the present study, humic acid was also observed to be in the same order as above, i.e., higher HA formation from the straw amended with saw dust, (sorghum straw + saw dust $-1.77 \%)>$ soybean straw $(1.45 \%)>$ finger millet straw $(1.34 \%)$ and $>$ sorghum straw (1.2\%) corroborating the above finding that higher the lignin content, higher the amount of the humic acid formed by the end of the composting process. Therefore, HA contents of the composts in the present study could improve water-holding capacity, $\mathrm{pH}$ buffering and thermal insulation (Stevenson 1984), and stimulate the activities of microfloral and microfaunal organisms within the soil environment (Burns et al. 1986).

\section{Seed germination assays and statistical analyses}

The seed germination index (GI) has been defined as a factor of relative seed germination and relative root elongation (Moharana and Biswas 2016). It was reported that immature and unstable composts cause phytotoxicity affecting seed germination and root growth and thus result in lower seed GIs (Raj and Antil 2011; Awasthi et al. 2014). Previous research efforts show that a GI value of $80 \%$ indicates maturity of the compost and the absence of phytotoxicity (Tiquia 2005; Huang et al. 2006). In the present study, when this observation was used as a benchmark to determine the phytotoxicity of the composts, results showed that finger millet straw compost at $100 \%$ extract application (no dilution) exhibited phytotoxicity in tomato and soybean resulting in $<80 \%$ of GI. Soybean straw (100\% extract) compost exhibited phytotoxicity only for tomato seeds with a GI $<80 \%$, whereas no phytotoxicity was observed in soybean and chickpea seeds at any dilution ( $>80 \% \mathrm{GI})$. Sorghum straw compost was also phytotoxic to tomato seeds at $100 \%$ extract application but not in soybean or chickpea seeds. On the other hand, compost obtained from sorghum straw + saw dust did not exhibit any phytotoxicity at any dilution in all the three tested seeds.

To confirm the above findings, we performed statistical analyses for the obtained data as explained in Sect. 2.5, by considering the type of compost as one factor and type of seed as the other factor. Tables 3, 4, 5 and Fig. 6 show the results of the ANOVA performed for the obtained
Table 3 Mean sum of squares for GI of composts obtained from straws of sorghum, finger millet, soybean and sorghum straw + saw dust (values inside parenthesis indicate degrees of freedom)

\begin{tabular}{llll}
\hline Source & Tomato & Chickpea & Soybean \\
\hline Compost $(C)$ & $1909.8^{\text {ns }}(3)$ & $1066.1^{\text {ns }}(3)$ & $6804.8^{* *}(3)$ \\
Extraction $(E)$ & $9557.5^{* *}(3)$ & $4697.0^{* *}(3)$ & $13108.7^{* *}(3)$ \\
$C \times E$ & $3314.3^{* *}(9)$ & $2978.4^{* *}(9)$ & $1942.1^{* *}(9)$ \\
Residual & $689.2(43)$ & $652.8(56)$ & $626.5(61)$ \\
\hline
\end{tabular}

**Means significant at $p<0.01$

$n s$ non-significant at $p \geq 0.05$

Table 4 LS Means for GI of composts obtained from straws of sorghum (SS), finger millet (FMS), soybean (SB) and sorghum + saw dust $(\mathrm{SS}+\mathrm{SD})$ when tested with tomato, chickpea and soybean seeds

\begin{tabular}{llrrr}
\hline Compost & Extract & Tomato seeds & $\begin{array}{l}\text { Chickpea } \\
\text { seeds }\end{array}$ & \multicolumn{1}{l}{$\begin{array}{l}\text { Soybean } \\
\text { seeds }\end{array}$} \\
\hline \multirow{3}{*}{ FMS } & Control & $80 \pm 13.1$ & $100 \pm 12.8$ & $85 \pm 11.2$ \\
& $25 \%$ extract & $108 \pm 11.7$ & $110 \pm 11.4$ & $67 \pm 12.5$ \\
& $50 \%$ extract & $53 \pm 15.2$ & $135 \pm 11.4$ & $107 \pm 12.5$ \\
& 100\% extract & $38 \pm 15.2$ & $153 \pm 12.8$ & $35 \pm 12.5$ \\
SB & 25\% extract & $99 \pm 13.1$ & $133 \pm 11.4$ & $144 \pm 11.2$ \\
& 50\% extract & $161 \pm 13.1$ & $116 \pm 11.4$ & $150 \pm 11.2$ \\
& $100 \%$ extract & $38 \pm 15.2$ & $81 \pm 11.4$ & $102 \pm 11.2$ \\
SS & $25 \%$ extract & $103 \pm 13.1$ & $173 \pm 11.4$ & $111 \pm 11.2$ \\
& $50 \%$ extract & $88 \pm 15.2$ & $138 \pm 12.8$ & $176 \pm 11.2$ \\
& $100 \%$ extract & $16 \pm 26.3$ & $79 \pm 12.8$ & $128 \pm 11.2$ \\
SS + SD & 25\% extract & $135 \pm 11.7$ & $108 \pm 12.8$ & $159 \pm 11.2$ \\
& $50 \%$ extract & $60 \pm 13.1$ & $139 \pm 11.4$ & $165 \pm 11.2$ \\
& $100 \%$ extract & $73 \pm 13.1$ & $114 \pm 11.4$ & $164 \pm 11.2$ \\
\hline
\end{tabular}

data. Statistical results show that at a $95 \%$ confidence level ( $\alpha=0.05$ ), main effect of compost is statistically significant for soybean seeds but not for tomato and chickpea, while the main and interaction effect of extraction and compost $\times$ extraction were significant for tomato, chickpea and soybean seeds (Table 3). In the following discussion section, we focused mainly on the results of $100 \%$ compost extracts rather than on the $25 \%, 50 \%$ and $75 \%$ extracts. This was done mainly to understand the phytotoxicity effects of the composts in a real time situation, when a farmer uses the compost as such instead of diluting it with water.

From Table 4, it can be observed that the LS means for GI was influenced by three factors, (1) one was the sensitive nature and health of the seeds at the time of germination, (2) nutrients availability in the medium grown (water in the control and compost extract in sample assays) and (3) the phytotoxicity of the compost extract. In the control assays, the LS means for GI was lower in the tomato than in chickpea and soy bean seeds indicating the sensitive nature of tomato seeds and robustness of chickpea and soybean seeds 
Table 5 Multiple comparisons of composts from the four agricultural straw residues

\begin{tabular}{|c|c|c|c|c|c|c|c|c|c|}
\hline \multirow[t]{2}{*}{ Effect } & \multicolumn{9}{|l|}{ Tomato } \\
\hline & Compost 1 & Extract 1 & Compost 2 & Extract 2 & Estimate & Standard error & DF & $t$ value & $\operatorname{Pr}>|t|$ \\
\hline \multirow[t]{7}{*}{ Compost $\times$ extract } & FMS & 100 & SB & 100 & -0.25 & 21.44 & 43 & -0.01 & 0.991 \\
\hline & FMS & 100 & SS & 100 & 21.80 & 30.31 & 43 & 0.72 & 0.476 \\
\hline & FMS & 100 & $\mathrm{SS}+\mathrm{SD}$ & 100 & -34.66 & 20.05 & 43 & -1.73 & 0.091 \\
\hline & SB & 100 & SS & 100 & 22.05 & 30.31 & 43 & 0.73 & 0.471 \\
\hline & SB & 100 & $\mathrm{SS}+\mathrm{SD}$ & 100 & -34.40 & 20.05 & 43 & -1.72 & 0.093 \\
\hline & SS & 100 & $\mathrm{SS}+\mathrm{SD}$ & 100 & -56.45 & 29.35 & 43 & -1.92 & 0.061 \\
\hline & \multicolumn{9}{|l|}{ Chickpea } \\
\hline Effect & Compost 1 & Extract 1 & Compost 2 & Extract 2 & Estimate & Standard error & $\mathrm{DF}$ & $t$ value & $\operatorname{Pr}>|t|$ \\
\hline \multirow[t]{7}{*}{ Compost $\times$ extract } & FMS & 100 & SB & 100 & 72.25 & 17.14 & 56 & 4.22 & 0.000 \\
\hline & FMS & 100 & SS & 100 & 74.92 & 18.07 & 56 & 4.15 & 0.000 \\
\hline & FMS & 100 & $\mathrm{SS}+\mathrm{SD}$ & 100 & 39.83 & 17.14 & 56 & 2.32 & 0.024 \\
\hline & SB & 100 & SS & 100 & 02.67 & 17.14 & 56 & 0.16 & 0.877 \\
\hline & SB & 100 & $\mathrm{SS}+\mathrm{SD}$ & 100 & -32.43 & 16.16 & 56 & -2.01 & 0.050 \\
\hline & SS & 100 & $\mathrm{SS}+\mathrm{SD}$ & 100 & -35.10 & 17.14 & 56 & -2.05 & 0.045 \\
\hline & \multicolumn{9}{|l|}{ Soybean } \\
\hline Effect & Compost 1 & Extract 1 & Compost 2 & Extract 2 & Estimate & Standard error & DF & $t$ value & $\operatorname{Pr}>|t|$ \\
\hline \multirow[t]{6}{*}{ Compost $\times$ extract } & FMS & 100 & SB & 100 & -67.67 & 16.79 & 61 & -4.03 & 0.000 \\
\hline & FMS & 100 & SS & 100 & -93.73 & 16.79 & 61 & -5.58 & 0.000 \\
\hline & FMS & 100 & $\mathrm{SS}+\mathrm{SD}$ & 100 & -129.33 & 16.79 & 61 & -7.70 & 0.000 \\
\hline & SB & 100 & SS & 100 & -26.06 & 15.83 & 61 & -1.65 & 0.105 \\
\hline & SB & 100 & $\mathrm{SS}+\mathrm{SD}$ & 100 & -61.66 & 15.83 & 61 & -3.90 & 0.000 \\
\hline & SS & 100 & $\mathrm{SS}+\mathrm{SD}$ & 100 & -35.61 & 15.83 & 61 & -2.25 & 0.028 \\
\hline
\end{tabular}

Statistical comparisons were made between $100 \%$ extracts of the composts that were tested using tomato, chickpea and soybean seeds

$F M S$ finger millet straw, $S B$ soybean straw, $S S$ sorghum straw, $S S+S D$ sorghum straw + saw dust

that could have directly influenced their rate of germination (GI). The assays of $100 \%$ compost extracts of Finger millet, soybean and sorghum straws showed quite low LS means for GI in tomato seeds which can be mainly attributed to the phytotoxic nature of the compost extracts at $100 \%$ concentration. The same straws did not show phytotoxic nature at $25 \%$ and $50 \%$ concentration for tomato seeds (Table 4). Similarly, $100 \%$ compost extract of finger millet straw was phytotoxic and, thus, showed low LS means in soybean seeds than when $25 \%$ and $50 \%$ of its extracts were tested. On the other hand, $100 \%$ compost extract of sorghum straw + saw dust showed high LS means indicating no phytotoxicity of the compost for all the three tested seeds (Table 4). This further indicates that the GI can only be dependent on the type of seed tested (for the seed germination assay) and that different seeds result in significantly different GIs as also reported by Dimitrios and Ioannis (2009). It can also be observed from Table 4 that $25 \%$ and $50 \%$ compost extracts did not show lower LS means for GI than controls which further confirms their phytotoxic nature towards tomato and soybean seeds. For chickpea and soybean seed types, all pair wise comparisons of compost means were statistically significant $(p<0.05)$ at $100 \%$ extraction except sorghum and soybean (Table 5). Furthermore, all pair-wise comparisons of compost means were non-significant $(p \geq 0.05)$ in tomato seed type at $100 \%$ extraction. This indicates and reinforces our finding that each compost could perform differently with different types of seeds. Furthermore, such interaction effects indicate that the main factor effects cannot be independently interpreted and that composts cannot be attributed mature and stable based upon a seed germination assay with one or two particular types of seeds.

Apparently, tomato seeds were found to be more sensitive than soybean or chickpea to the composts when tested at $100 \%$ extract application. Furthermore, finger millet straw compost was found to be more phytotoxic and less mature than soybean, sorghum or sorghum straw + saw dust composts as it showed $<80 \%$ GI in more than one seed type and in more than one dilutions. Also, the results of germination assays performed with finger millet straw compost were found to be inconclusive as the compost yielded phytotoxicity at $25 \%$ and $100 \%$ extract applications but not at 

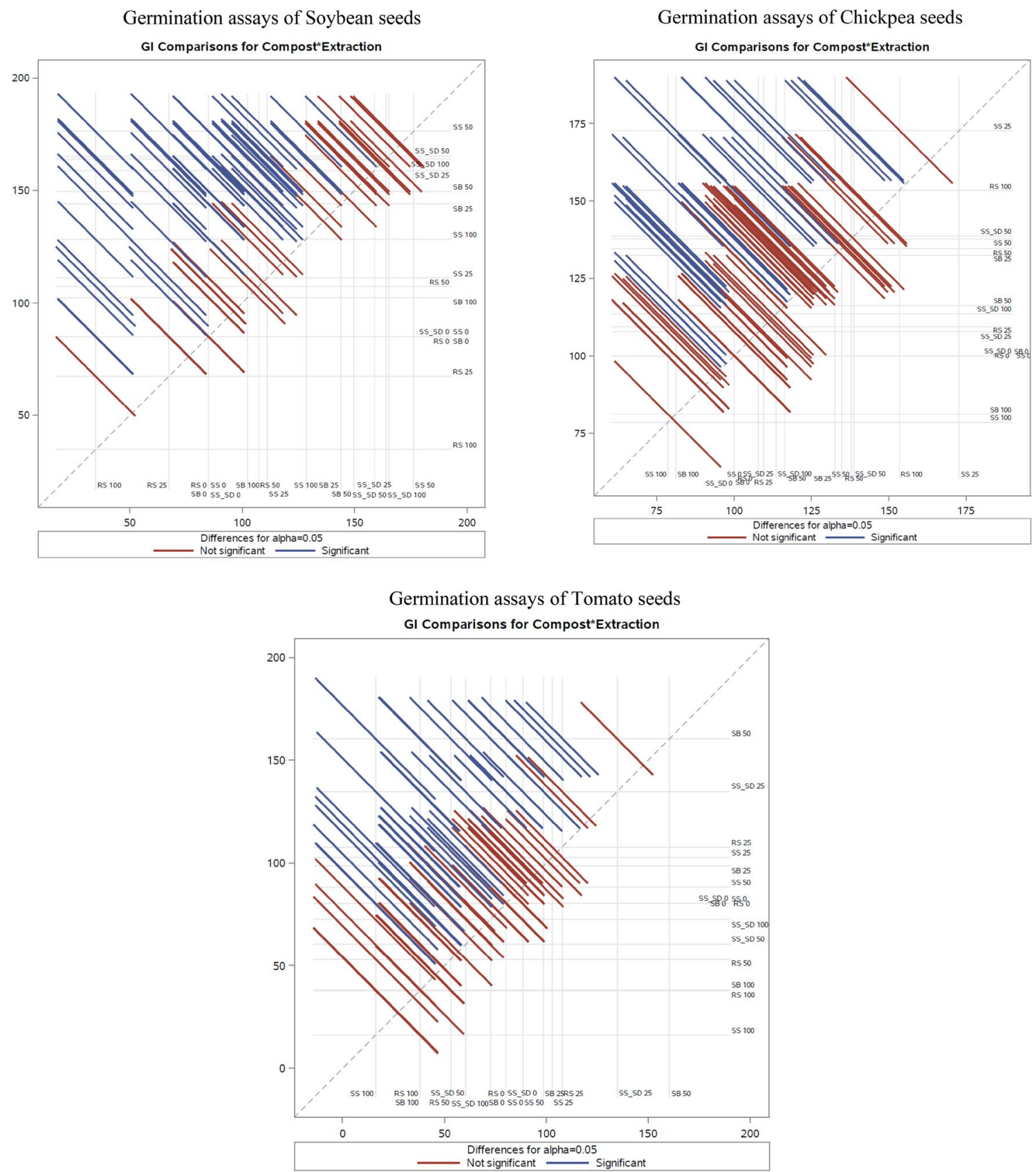

Fig. 6 Multiple comparison plots of Germination Indices of four composts and their extracts $(25 \%, 50 \%$ and $100 \%)$ obtained during seed germination assays of tomato, chickpea and soybean. Red bars show "not significant" and blue bars show "significant" results of ger-

$50 \%$ extract application indicating some error either during the assay preparation, testing or some abnormality of seeds.

A much older research study by Aggelis et al. (2002) reported the following categories to characterize different composts/substrates. The study proposed that, if the GI value is $<65 \%$, then the compost/substrate was characterized as phytotoxic; if GI value was $66 \%<100 \%$, then the compost/ substrate was characterized as a stable, non-phytotoxic mination indices of the four composts and their extracts. $S B$ soybean straw, $S S$ sorghum straw, $R S$ finger millet straw, $S S+S D$ sorghum straw + saw dust

and could be applied for agricultural purposes; and if the GI $>101 \%$, the compost/substrate was characterized as phytonutrient-phytostimulant and could be used as fertilizer in agriculture. When above findings are applied to the present study, phytotoxicity appeared to be seed specific rather than compost specific, as composts from finger millet straw, soybean straw and sorghum straw showed GI $<65 \%$ only in tomato seeds (at $100 \%$ extract application) whereas in 
soybean seeds, finger millet straw compost was found to be phytotoxic (at 25\% dilution and 100\% extract) indicating more further tests to be performed. In chickpea seeds none of the composts exhibited any phytotoxic nature. Therefore, the characterization proposed by Aggelis et al. (2002) should be carefully applied considering also the sensitivity of the seeds tested in addition to the phytotoxic nature of the composts/substrates.

Furthermore, Zucconi et al. (1981a, b), reported that during the decomposition process, some toxins (organic acids for example) are produced as a result of organic matter hydrolysis and get quickly converted into other byproducts or get inactivated by microorganisms. However, it seems that if the first contact of the organic matter does not induce toxicity to the root materials, then the plant somehow shows a capability to recover and survive further (Moharana and Biswas 2016). This theory could somewhat explain the reason behind how the phytotoxic nature of finger millet straw compost was affecting GI in tomato and soybean seeds but not in Chick pea seeds. Chick pea seeds exhibited a capacity to withstand the phytotoxic nature of the composts in comparison to tomato and soybean seeds.

\section{Conclusions}

In the present study, physico-chemical and microbiological parameters of composts obtained from sorghum straw and sorghum straw + saw dust indicated better decomposition pattern than from soybean and finger millet straws as evident by decrease in $\mathrm{C} / \mathrm{N}$ ratio (from an initial 41-61 to 10-17) and microbial VS (organic matter) destruction, EC and $\mathrm{HA}$ formation. Elemental analyses showed progressive increase in micro ( $\mathrm{Fe}, \mathrm{Mn}, \mathrm{Cu}, \mathrm{Zn}$ and $\mathrm{B}$ ) and macronutrient $(\mathrm{N}, \mathrm{P}, \mathrm{K}, \mathrm{Ca}, \mathrm{Mg}, \mathrm{S})$ composition indicating overall better decomposition pattern in composts of sorghum straw and sorghum straw + saw dust than in soybean and finger millet straws. Statistical analyses of GI experiments using tomato, soybean and chickpea seeds confirmed that only the compost obtained from sorghum straw + saw dust was mature, stable and free from any phytotoxicity as all the seeds showed statistically significant GIs. Furthermore, it was difficult to attribute a single threshold GI value to indicate maturity of a compost and cannot further be applied to different types of composts as different seeds responded differently to the same compost. Nonetheless, the present study showed that straw residues can be efficiently composted and enhance their mineralized elemental composition $(\mathrm{C}, \mathrm{N}, \mathrm{P}, \mathrm{K})$ which can help to improve the health of the agricultural soils and contribute to organic as well as sustainable farming.

Acknowledgements We gratefully acknowledge Ms. Chetna Nimje for carrying out the elemental analyses (ICPOES) of the samples. We also thank Dr. Keshava Rao and his team for helping us with the data logger systems to record the temperature data during the study period.

Open Access This article is distributed under the terms of the Creative Commons Attribution 4.0 International License (http://creativeco mmons.org/licenses/by/4.0/), which permits unrestricted use, distribution, and reproduction in any medium, provided you give appropriate credit to the original author(s) and the source, provide a link to the Creative Commons license, and indicate if changes were made.

\section{References}

Aggelis G, Ehaliotis C, Nerud F, Stoychiev I, Luberatos G, Zervakis G (2002) Evaluation of white-rot fungi for detoxification and decoloration of effluents from the green olives debittering process. Appl Microbiol Biotechnol 59:353-360. https://doi.org/10.1007/s0025 3-002-1005-9

APHA (1998) Standard methods for the examination of water and wastewater, 20th edn. American Public Health Association, Washington

Awasthi MK, Pandey AK, Khan J, Bundela PS (2014) Evaluation of thermophilic fungal consortium for organic municipal solid waste composting. Bioresour Technol 168:214-221. https://doi. org/10.1016/j.biortech.2014.01.048

Badu M, Twumasi SK, Boadi NO (2011) Effects of lignocellulosic in wood used as substrate on the quality and yield of mushrooms. Food Nutr Sci 2:780-784. https://doi.org/10.4236/fns.2011.27107

Bernal MP, Alburquerque JA, Moral R (2009) Composting of animal manures and chemical criteria for compost maturity assessment. Annu Rev Bioresour Technol 100:5444-5453. https://doi. org/10.1016/j.biortech.2008.11.027

Burns RG, Dell Agnola G, Miele S, Nardi S, Savioni G, Schnitzer M, Sequi P, Vaughan D (1986) Humic substances: effects on soil and plants. REDA, Rome

Cáceres R, Narcís C, Krystyna M, Oriol M (2015) Evolution of process control parameters during extended co-composting of green waste and solid fraction of cattle slurry to obtain growing media. Bioresour Technol 179:398-406. https://doi.org/10.1016/j.biort ech.2008.11.027

Chauhan HK, Singh K (2013) Effect of tertiary combinations of animal dung with agrowastes on the growth and development of earthworm Eisenia fetida during organic waste management. Int J Recy Org Agric 2:11. https://doi.org/10.1186/2251-7715-2-11

Christl I, Metzger A, Heidmann L, Kretzschmar R (2005) Effect of humic and fulvic acid concentrations and ionic strength on copper and lead binding. Environ Sci Technol 39:5319-5326. https://doi. org/10.1021/es050018f

Diaz LF, Savage GM, Golueke CG (2002) Composting of municipal solid wastes. In: Tchobanoglous G, Kreith F (eds) Handbook of solid waste management. McGraw-Hill Inc, New York, pp 12.1-12.7

Dimitrios PK, Ioannis ST (2009) A statistical analysis to assess the maturity and stability of six composts, laboratory of solid and hazardous waste management. Department of Environmental Engineering, Democritus University of Thrace Xanthi, Greece. https://doi.org/10.1016/j.wasman.2008.10.016

Epstein E (1997) The science of composting. Technomic Publishing Co Inc, Lancaster, pp 109-113 (See also 126-129)

Gabhane J, William SP, Bidyadhar R, Bhilawe P, Anand D, Vaidya AN, Wate SR (2012) Additives aided composting of green waste: effects on organic matter degradation, compost maturity, and quality of the finished compost. Bioresour Technol 114:382-388. https ://doi.org/10.1016/j.biortech.2012.02.040 
Goyal S, Dhull SK, Kapoor KK (2005) Chemical and biological changes during composting of different organic wastes and assessment of compost maturity. Bioresour Technol 96:1584-1591. https://doi.org/10.1016/j.biortech.2004.12.012

Guo R, Li G, Jiang T, Schuchardt F, Chen T, Zha Y, Shen Y (2012) Effect of aeration rate, $\mathrm{C} / \mathrm{N}$ ratio and moisture content on the stability and maturity of compost. Bioresour Technol 112:171-178. https://doi.org/10.1016/j.biortech.2012.02.099

Hanc A, Szakova J, Ochecova P (2014) Differences in the mobility of $\mathrm{Cd}, \mathrm{Cu}, \mathrm{Pb}$ and $\mathrm{Zn}$ during composting of two types of household bio-waste collected in four seasons. Bioresour Technol 168:204-213. https://doi.org/10.1016/j.biortech.2014.01.125

Harrison RB (2008) Composting and formation of humic substances. Encycl Ecol. https://doi.org/10.1016/B978-008045405-4.00262 $-7$

Hiloidhari M, Baruah DC (2014) Bioenergy potential from crop residue biomass in India. Renew Sustain Energy Rev 32:504-512. https:// doi.org/10.1016/j.rser.2014.01.025

Himanen M, Hanninen K (2011) Composting of bio-waste, aerobic and anaerobic sludges-effect of feedstock on the process and quality of compost. Bioresour Technol 102:2842-2852. https:// doi.org/10.1016/j.biortech.2010.10.059

Hseu Z-Y (2004) Evaluating heavy metal contents in nine composts using four digestion methods. Bioresour Technol 95:53-59. https ://doi.org/10.1016/j.biortech.2004.02.008

Huang GF, Wu QT, Wong JWC, Nagar BB (2006) Transformation of organic matter during co-composting of pig manure with sawdust. Bioresour Technol 97:1834-1842. https://doi.org/10.1016/j.biort ech.2005.08.024

Hue NV, Liu J (1995) Predicting compost stability. Compost Sci Util 3:8-15. https://doi.org/10.1080/1065657X.1995.10701777

Iannotti DA, Pang T, Toth BL, Elwell DL, Keener HM, Hoitink HAJ (1993) A quantitative respirometric method for monitoring compost stability. Compost Sci Util 1:52-65. https://doi. org/10.1016/0167-8809(92)90154-4

Inbar Y, Chen Y, Hadar Y (1990) Humic substance formed during the composting of organic matter. Soil Sci Soc Am J 54:1316-1323. https://doi.org/10.2136/sssaj1990.03615995005400050019x

Kumar A, Kumar N, Baredar P, Shukla A (2015) A review on biomass energy resources, potential, conversion and policy in India. Renew Sust Energy Rev 45:530-539. https://doi.org/10.1016/j. rser.2015.02.007

Lashermes G, Barriuso E, Houot S (2012) Dissipation pathways of organic pollutants during the composting of organic wastes. Chemosphere 87:137-143. https://doi.org/10.1016/j.chemospher e.2011.12.004

Lopez MJ, Elorrieta MA, Vargas-Garcı́́ MC, Suárez-Estrella F, Moreno J (2002) The effect of aeration on the biotransformation of lignocellulosic wastes by white-rot fungi. Bioresour Technol 81:123-129. https://doi.org/10.1016/S0960-8524(01)00112-2

Manios T (2004) The composting of different organic solid wastes: experience from the island of Crete. Environ Int 29:1079-1089. https://doi.org/10.1016/S0160-4120(03)00119-3

Matthew SW, Teresa OF, Lyndon TP (2011) A cost-effective acid digestion method using closed polypropylene tubes for inductively coupled plasma optical emission spectrometry (ICP-OES) analysis of plant essential elements. Anal Methods 3:2854-2863. https:// doi.org/10.1039/C1AY05430A

McIntosh TV (2010) Enhanced enzyme saccharification of Sorghum bicolor straw using dilute alkali pretreatment. Bioresour Technol 101:6718-6727. https://doi.org/10.1016/j.biortech.2010.03.116

Mhindu RL, Menas W, Esther N (2013) Composting of selected organic wastes from peri-urban areas of Harare, Zimbabwe. Int J Recycl Org Waste Agricult 2:14. https://doi.org/10.1186/2251-7715-2-14

Moharana PC, Biswas DR (2016) Assessment of maturity indices of rock phosphate enriched composts using variable crop residues.
Bioresour Technol 222:1-13. https://doi.org/10.1016/j.biort ech.2016.09.097

Mupondi LT, Mnkeni PNS, Brutsch MO (2006) The effects of goat manure, sewage sludge and effective microorganisms on the composting of pine bark. Compost Sci Util 14:201-210. https://doi. org/10.1080/1065657X.2006.10702284

Nakasaki K, Marui T (2011) Progress of organic matter degradation and maturity of compost produced in a large-scale composting facility. Waste Manag Res 29:574-581. https://doi. org/10.1177/0734242X10389105

Nolan T, Troy SM, Healy MG, Kwapinski W, Leahy JJ, Lawlor PG (2011) Characterization of separated pig manure composted with a variety of bulking agents 513 at low initial $\mathrm{C} / \mathrm{N}$ ratios. Bioresour Technol 102:7131-7138. https://doi.org/10.1016/j.biort ech.2011.04.066

Pan I, Dam B, Sen SK (2012) Composting of common organic wastes using microbial inoculants. 3 Biotech 2:127-134. https://doi. org/10.1007/s13205-011-0033-5

Raj D, Antil RS (2011) Evaluation of maturity and stability parameters of composts prepared from agro-industrial wastes. Bioresour Technol 102:2868-2873. https://doi.org/10.1016/j.biort ech.2010.10.077

Rashad FM, Saleh WD, Moselhy MA (2010) Bioconversion of rice straw and certain agro-industrial wastes to amendments for organic farming systems: composting quality, stability and maturity indices. Bioresour Technol 101:5952-5960. https://doi. org/10.1016/j.biortech.2010.02.103

Ryckeboer J, Mergaert J, Coosemans J, Deprins K, Swings J (2003) Microbiological aspects of biowaste during composting in a monitored compost bin. J Appl Microbiol 94:127-137. https://doi.org /10.1046/j.1365-2672.2003.01800.x

Sahrawat KL, Ravi Kumar G, Murthy KVS (2002) Sulfuric acidSelenium digestion for multi-element analysis in a single plant digest. Commun Soil Sci Plant Anal 33:3757-3765. https://doi. org/10.1081/CSS-120015920

Sánchez-Monedero MA, Roig A, Paredes C, Bernal MP (2001) Nitrogen transformation during organic waste composting by the Rutgers system and its effects on $\mathrm{pH}, \mathrm{EC}$ and maturity of the composting mixtures. Bioresour Technol 78:301-308. https://doi. org/10.1016/S0960-8524(01)00031-1

Singh S, Nain L (2014) Microorganisms in the conversion of agricultural wastes to compost. Proc Indian Natl Sci Acad 80:473-481. https://doi.org/10.16943/ptinsa/2014/v80i2/7

Stevenson FJ (1984) Humic chemistry: genesis, composition, reactions. Wiley, New York

Tiquia SM (2005) Microbiological parameters as indicators of compost maturity. J Appl Microbiol 99:816-828. https://doi.org/10.1 111/j.1365-2672.2005.02673.x

Tiquia SM, Tam NFY, Hodgkiss IJ (1996) Microbial activities during composting of spent pig-manure sawdust litter at different moisture contents. Bioresour Technol 55:201-206. https://doi. org/10.1016/0960-8524(95)00195-6

Troy SM, Nolan T, Kwapinski W, Leahy JJ, Healy MG, Lawlor P (2012) Effect of sawdust addition on composting of separated raw and anaerobically digested pig 3 manure. J Environ Manag 111:70-77. https://doi.org/10.1016/j.jenvman.2012.06.035

Veeken A, Nierop K, De Wilde V, Hamelers B (2000) Characterization of $\mathrm{NaOH}$-extracted humic acids during composting of a biowaste. Bioresour Technol 72:33-41. https://doi.org/10.1016/ S0960-8524(99)90096-2

Villar I, Alves D, Garrido J, Mato S (2016) Evolution of microbial dynamics during the maturation phase of the composting of different types of waste. Waste Manag 54:83-92. https://doi. org/10.1016/j.wasman.2016.05.011

Wei Y, Zhao Y, Xi B, Wei Z, Li Z, Cao Z (2015) Changes in phosphorus fractions during organic wastes composting from 
different sources. Bioresour Technol 189:349-356. https://doi. org/10.1016/j.biortech.2015.04.031

Wong JWC, Mak KF, Chan NW, Lam A, Fang M, Zhou LX (2001) Co-composting of soybean residues and leaves in Hong Kong. Bioresour Technol 76:99-106. https://doi.org/10.1016/S0960 -8524(00)00103-6

Wu L, Ma LQ, Martinez GA (2000) Comparison of methods for evaluating stability and maturity of biosolids compost. J Environ Qual 29:424-429. https://doi.org/10.2134/jeq2000.004724250029000 $20008 \mathrm{x}$

Yadav A, Garg VK (2011) Recycling of organic wastes by employing Eisenia fetida. Bioresour Technol 102:2874-2880. https://doi. org/10.1016/j.biortech.2010.10.083

Zhou Y, Selvam A, Wong JWC (2014) Evaluation of humic substances during co-composting of food waste, sawdust and Chinese medicinal herbal residues. Bioresour Technol 168:229-234. https ://doi.org/10.1016/j.biortech.2014.05.070

Zucconi F, Pera A, Forte M, de Bertoldi M (1981a) Evaluating toxicity of immature compost. Biocycle 22:54-57

Zucconi F, Forte M, Monac A, Beritodi M (1981b) Biological evaluation of compost maturity. Biocycle 22:27-29

Publisher's Note Springer Nature remains neutral with regard to jurisdictional claims in published maps and institutional affiliations. 